\title{
Nocardia vermiculata sp. nov. and Nocardia thailandica sp. nov. Isolated from Clinical Specimens
}

\author{
Akiko Kageyama, ${ }^{1}$ Natteewan Poonwan, ${ }^{2}$ Katsukiyo Yazawa, ${ }^{1}$ Shin-ichi Suzuki, ${ }^{3}$ \\ Reiner M. Kroppenstedt, ${ }^{4}$ and Yuzuru Mikami ${ }^{1 *}$ \\ ${ }^{1}$ Research Center for Pathogenic Fungi and Microbial Toxicoses, Chiba University, \\ 1-8-1 Inohana, Chuo-ku, Chiba 260-8673, Japan \\ ${ }^{2}$ Division of Mycology, National Institute of Health, Department of Medical Sciences, Nonthaburi, Thailand \\ ${ }^{3}$ Discovery Research Laboratories, Tanabe Seiyaku Co., Ltd., 2-2-50 Kawagishi, \\ Toda, Saitama 335-8505, Japan \\ ${ }^{4}$ Deutsche Sammlung von Mikroorganismen und Zellkulturen Mascheroder Weg 1b, D-38124 Baunscheweig, Germany \\ (Received Aug. 9, 2004 / Accepted Nov. 18, 2004)
}

\begin{abstract}
The taxonomic positions of actinomycetes isolated from clinical specimens in Japan and Thailand were examined using a polyphasic approach. The strains IFM $0391^{\mathrm{T}}$ and IFM $10145^{\mathrm{T}}$ were found to have morphological, biochemical and chemotaxonomic properties consistent with their classification in the genus Nocardia. DNA-DNA hybridization, coupled with sequence analysis of 16S rDNA, indicated that these strains belong to two new species of the genus Nocardia: Nocardia vermiculata for IFM $0391^{\mathrm{T}}$ $\left(=\right.$ NBRC $\left.1000427^{\mathrm{T}}=\mathrm{JCM} 12345^{\mathrm{T}}=\mathrm{DSM} 44807^{\mathrm{T}}\right)$, and Nocardia thailandica for IFM $10145^{\mathrm{T}}(=\mathrm{NBRC}$ $100428^{\mathrm{T}}=$ JCM $12356^{\mathrm{T}}=$ DSM 44808 ${ }^{\mathrm{T}}$.
\end{abstract}

\section{INTRODUCTION}

Nocardia is a filamentous, Gram-positive, partially acidfast, branched bacterium, with the typical habitat of a soil saprophyte, and classified as an aerobic actinobacteria ${ }^{1,2}$. Most Nocardia species can cause human infections that are difficult to diagnose due to non-specific clinical and histological manifestations ${ }^{1-3)}$. Therefore, for definitive diagnosis and effective therapy, identification of Nocardia species is required ${ }^{4-8)}$. Nocardia asteroides is considered the major cause of nocardiosis; however, many taxonomic studies have repeatedly reported that $N$. asteroides is a heterogeneous species ${ }^{9,10)}$. Two strains with similar morphological and biochemical characteristics to $N$. asteroides were isolated from clinical specimens and used in this study. Present taxonomic studies revealed that the strains, IFM $10145^{\mathrm{T}}$ and IFM $0391^{\mathrm{T}}$, were loosely associated with $N$. asteroides, $N$. caishijiensis and $N$. neocaledoniensis, and $N$. africana, $N$. cerradoensis, $N$. nova, $N$. vaccinii, $N$. veterana, and $N$. vinacea, respectively. However, these strains were found to be delineated from $N$. asteroides and $N$. africana and related species based on comparative DNADNA relatedness data. Therefore, these two strains were found to represent new species within the genus Nocardia. We propose the new species designations Nocardia vermiculata sp. nov. and Nocardia thailandica sp. nov.

\section{MATERIALS AND METHODS}

Organism and cultivation: IFM $0391^{\mathrm{T}}$ was isolated from sputum of a 63-year-old Japanese male patient in 1985.
IFM $10145^{\mathrm{T}}$ was isolated from pus of a Thai patient. Strain IFM $0391^{\mathrm{T}}$, IFM $10145^{\mathrm{T}}, N$. asteroides, $N$. africana, $N$. cerradoensis, $N$. nova, $N$. vaccinii, $N$. veterana and $N$. vinacea were cultured on Muller Hinton II (MH II) agar slant with $1 \%$ glucose and $1 \%$ glycerol for 1 week at $27^{\circ} \mathrm{C}$. For extraction of DNA and sequencing, bacterial strains were cultured on Brain Heart Infusion (BHI, Difco) broth for 4 days at $32^{\circ} \mathrm{C}$. Bacterial strains were cultured on BHI broth with $2 \%$ glucose and $2 \%$ glycine for 3 days at $32^{\circ} \mathrm{C}$ for DNA-DNA hybridization.

Biochemical and chemotaxonomical characterization: Decomposition of adenine, casein, hypoxanthine, tyrosine, urea, and xanthine were examined using the methods of Gordon et al. ${ }^{11)}$ Acid production from carbohydrates, utilization of organic acids, and growth temperature were determined by the modified method of Poonwan et al. ${ }^{7)}$. Isolated strains were tested for their ability to grow in $\mathrm{MH}$ II agar with $0.2 \%$ glucose with each antibiotic TRIDISK (Eiken, Japan, Tokyo) at $32^{\circ} \mathrm{C}$ for 2 or 3 days ${ }^{12}$.

Whole cell hydrolysates were analyzed for diaminopimelic acid isomers using thin layer chromatography (TLC) ${ }^{13)}$. Whole cell sugars were prepared as previously reported ${ }^{14)}$ and analyzed by TLC $^{15}$. Mycolic acids were prepared as previously reported ${ }^{16)}$. Menaquinones were extracted from freeze-dried biomass (500 mg) and analyzed as described by Chun \& Goodfellow ${ }^{17)}$.

Fatty acid methyl-esters were prepared and analyzed as previously described ${ }^{18)}$ using the standard Microbial Identification System (Midi, Inc., Del., U.S.A.) for automated gas chromatographic analyses ${ }^{19,20)}$.

DNA analysis: Genomic DNA samples for sequencing

* Corresponding author. Phone: +81-43-226-2493. Fax: +81-43-226-2486. E-mail: mikami@faculty.chiba-u.jp 
were prepared using the guanidine thiocyanate method ${ }^{21,22)}$. A nearly complete $16 \mathrm{~S}$ rRNA gene sequence of the isolated strain was determined. The $16 \mathrm{~S}$ rDNA was amplified and sequenced using PCR and prokaryotic 16S rDNA universal primers 8F (5'-AGAGTTTGATCCTGGCTCAG-3') and 691R (5'-ACCGCTACACCAGGA-3'), 520F (5'-CAGCAGCCGCGGTAATAC-3') and 1100R (5'-GGGTTGCGCTGTTG-3'), and 926F (5'-AAACTCAAAGGAATTGACGG-3') and 1542R (5'-ACAAAGGAGGTGATC-3'). PCR was performed with a DNA thermal cycler (TaKaRa, Tokyo, Japan) using 35 cycles and consisting of denaturation at $94^{\circ} \mathrm{C}$ for $60 \mathrm{~s}$, primer annealing at $60^{\circ} \mathrm{C}$ for $60 \mathrm{~s}$, and primer extension at $72^{\circ} \mathrm{C}$ for $120 \mathrm{~s}$. The PCR products were purified with a CentriSep column (Princeton Separations). The DNA sequences were determined with an automatic sequence analyzer (ABI PRISM $^{\mathrm{TM}}$ 3100; PE Applied Biosystems, CA, U.S.A.) using a dye terminator cycle sequencing kit (PE Applied Biosystems).

BLAST analysis against various sequence databases was used to identify strains related to the IFM $0391^{\mathrm{T}}$ and IFM $10145^{\mathrm{T}}$ strains. Sequence data of related species were retrieved from GenBank. Nucleotide substitution rates $\left(\mathrm{K}_{\mathrm{NUC}}\right.$ values) were calculated $\left.{ }^{23}\right)$ and phylogenetic trees were constructed by the neighbor-joining method ${ }^{24)}$. The topology of the trees was evaluated by bootstrap analysis of the sequence data using CLUSTAL W software ${ }^{25)}$. The DNAML program in the PHYLIP 3.5c package ${ }^{26)}$ was used for Maximum Likelihood analysis, with the default transition/transversion ratio of 2.000000 . The sequence similarity values were calculated manually.

DNA was isolated as described by Saito \& Miura ${ }^{27)}$ with modification. DNA base composition was estimated by high performance liquid chromatography (HPLC) ${ }^{28)}$. Levels of DNA-DNA relatedness were determined by the method of Ezaki et al. ${ }^{29)}$ using photobiotin and microplates.

\section{RESULTS AND DISCUSSION}

The chemotaxonomic and morphological characteristics of the two isolated strains are consistent with their assignment to the genus Nocardia ${ }^{30,31)}$. All of them contain galactose and arabinose as characteristic whole-cell sugars in addition to meso-diaminopimelic acid as the wall diamino acid, and a mycolic acid that co-migrated ( $R f$ value of about 0.47 ) with those extracted from marker Nocardia strains. Major menaquinones were $\mathrm{MK}-8\left(\mathrm{H}_{4 \omega \text {-cycl. }}\right)$. Analysis of the fatty acids of the two isolated strains IFM $0391^{\mathrm{T}}$ and IFM $10145^{\mathrm{T}}$ by GLC revealed the expected pattern that is diagnostic of members of the genus Nocardia and related taxa; that is, straight-chain saturated and unsaturated fatty acids together with a diagnostic amount of tuberculostearic acid (10-methyl-branched octadecanoid acid) (Table 1).

The physiological properties of strains IFM $0391^{\mathrm{T}}$ and IFM $10145^{\mathrm{T}}$ are shown in Table 2 . Susceptibility testing
Table 1 Fatty acid composition of strains IFM $0391^{\mathrm{T}}$ and IFM $10145^{\mathrm{T}}$

\begin{tabular}{|c|c|c|}
\hline Fatty acid (\%) & IFM $0391^{\mathrm{T}}$ & IFM $10145^{\mathrm{T}}$ \\
\hline $12: 0$ & 0.3 & - \\
\hline $13: 1$ & 0.8 & - \\
\hline 13:0 & 0.4 & - \\
\hline 14:0 & 5.4 & 0.3 \\
\hline unknown ECL 14.959 & 3.1 & - \\
\hline cis-9-15:1 & - & 0.9 \\
\hline $15: 0$ & 1.6 & 3.4 \\
\hline cis-8-16:1 & 1.6 & - \\
\hline cis-9-16:1 & 7.9 & 15.9 \\
\hline 16:0 & 33.9 & 27.9 \\
\hline 10-Methyl-16:0 & - & 0.2 \\
\hline cis-10-17:1 & 0.6 & - \\
\hline cis-9-17:1 & 1.7 & 1.9 \\
\hline $17: 0$ & 6.0 & 9.7 \\
\hline 10-Methyl-17:0 & 0.5 & 2.2 \\
\hline cis-9-18:1 & 12.7 & 3.1 \\
\hline cis-11-18:1 & 0.5 & - \\
\hline $18: 0$ & 12.3 & 10.2 \\
\hline 11-Methyl-18:0 & 1.1 & - \\
\hline 10-Methyl-18:0 & 9.0 & 21.5 \\
\hline cis-9 19:1 & 0.4 & 2.1 \\
\hline 19:0 & - & 0.6 \\
\hline 20:0 & - & 0.2 \\
\hline
\end{tabular}

Abbreviations: ECL, equivalent chain length

cis-9 18:1, cis-9 octadecenoic acid (oleic acid); 10-methyl-18:0, 10-methyl-octadecanoic acid (tuberculostearic acid)

of clinical isolates of Nocardia to antimicrobials is useful in grouping organisms. IFM $0391^{\mathrm{T}}$ and IFM $10145^{\mathrm{T}}$ were susceptible to 5-fluorouracil, and this characteristic was useful for discrimination of both strains from other reference Nocardia strains $^{12)}$.

Almost complete 16S rDNA sequences were determined for IFM $0391^{\mathrm{T}}(1367 \mathrm{bp})$ and IFM $10145^{\mathrm{T}}(1440 \mathrm{bp})$, and their sequences have been deposited in the DDBJ database. A database search demonstrated that the isolated strains belong to the suborder Corynebacterineae and the family Nocardiaceae ${ }^{32)}$. It is clear from the phylogenetic trees (Figs. 1, 2) that IFM $0391^{\mathrm{T}}$ is loosely associated with $N$. africana, $N$. cerradoensis, $N$. nova, $N$. vaccinii, $N$. veterana, and $N$. vinacea, and IFM $10145^{\mathrm{T}}$ is loosely associated with $N$. asteroides, $N$. caishijiensis and $N$. neocaledoniensis. The sequence similarity value between IFM $0391^{\mathrm{T}}$ and the 6 related species was $97.5-98.5 \%$, between IFM $10145^{\mathrm{T}}$ and $N$. asteroides was $98.7 \%$, IFM $10145^{\mathrm{T}}$ and $N$. neocaledoniensis was $97.8 \%$, and IFM $10145^{\mathrm{T}}$ and $N$. caishijiensis was $97.8 \%$. These sequence similarity values are not so high for the same species. Therefore, we checked the similarity of these strains based on DNA-DNA hybridization with related valid species. The DNA-DNA relatedness between IFM $0391^{\mathrm{T}}$ and related Nocardia species was $<46 \%$ (Table 3 ) and between IFM 10145 


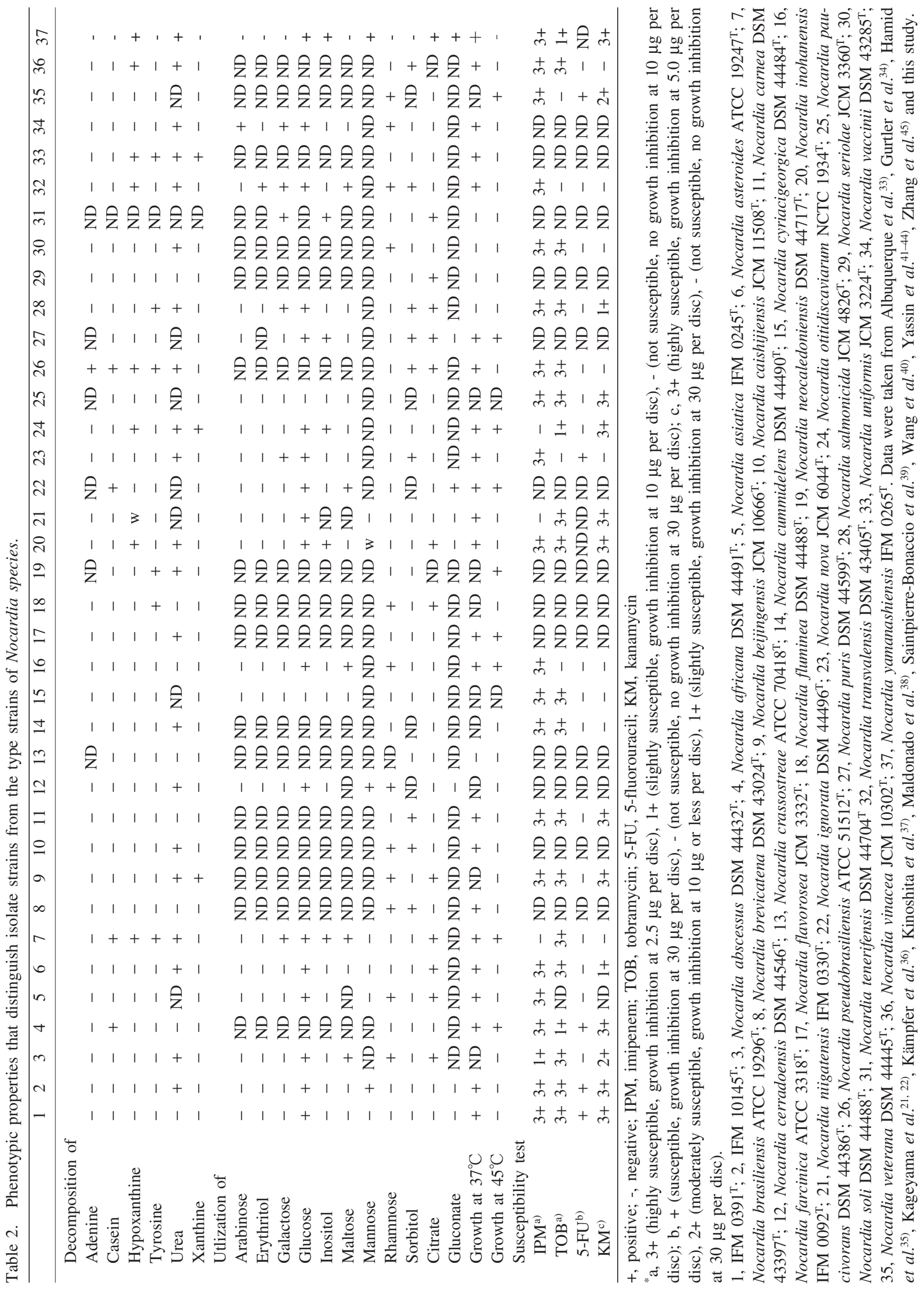


and $N$. asteroides was $<12 \%$, showing that these two isolated strains could each represent a new species.

Based on the phylogenetic and phenotypic data described above, we concluded that IFM $0391^{\mathrm{T}}$ and IFM $10145^{\mathrm{T}}$ are two new species in the genus Nocardia, and we propose the new species names of Nocardia vermiculata sp. nov. for IFM $0391^{\mathrm{T}}$ and Nocardia thailandica $\mathrm{sp}$. nov. for IFM $10145^{\mathrm{T}}$.

\section{Description of Nocardia vermiculata sp. nov.}

Nocardia vermiculata (L. fem. part. adj. vermiculata, in the form of worms, referring to the morphology of the aerial mycelium).

Aerobic, Gram-positive, partially acid-fast, non-motile actinomycetes forming beige colored substrate mycelium. The cells have typical Nocardia micromorphology of branched vegetative hyphae, fragmented into oval to rodshaped elements $(0.4-0.7$ by $0.7-1.0 \mu \mathrm{m})$. The aerial mycelium is moderate and orange to pale orange brown. Colonies are $0.3-1.0 \mathrm{~mm}$ in diameter after 7 days at $30^{\circ} \mathrm{C}$ on MH11 agar with $0.2 \%$ glucose. Short chains of conidia are found on the aerial mycelium. The aerial mycelium shows primitive spiral-like structures (worm-like structures). They produce faint brown soluble pigment. Glucose is utilized, but arabinose, erythritol, galactose, inositol, maltose, mannose, rhamnose, sorbitol, gluconate, and citrate are not. Adenine, casein, hypoxanthine, tyrosine, urea, and xanthine are not decomposed. The strain grows at $37^{\circ} \mathrm{C}$ but not $45^{\circ} \mathrm{C}$. The $\mathrm{G}+\mathrm{C}$ content of the DNA is $67-$ mol\%. The strain is a clinical isolate from sputum of a Japanese male patient. The type strain of Nocardia vermiculata is IFM $0391^{\mathrm{T}}\left(=\mathrm{NBRC} 100427^{\mathrm{T}}=\mathrm{JCM} 12345^{\mathrm{T}}\right.$ $=\operatorname{DSM} 44807^{\mathrm{T}}$ ).

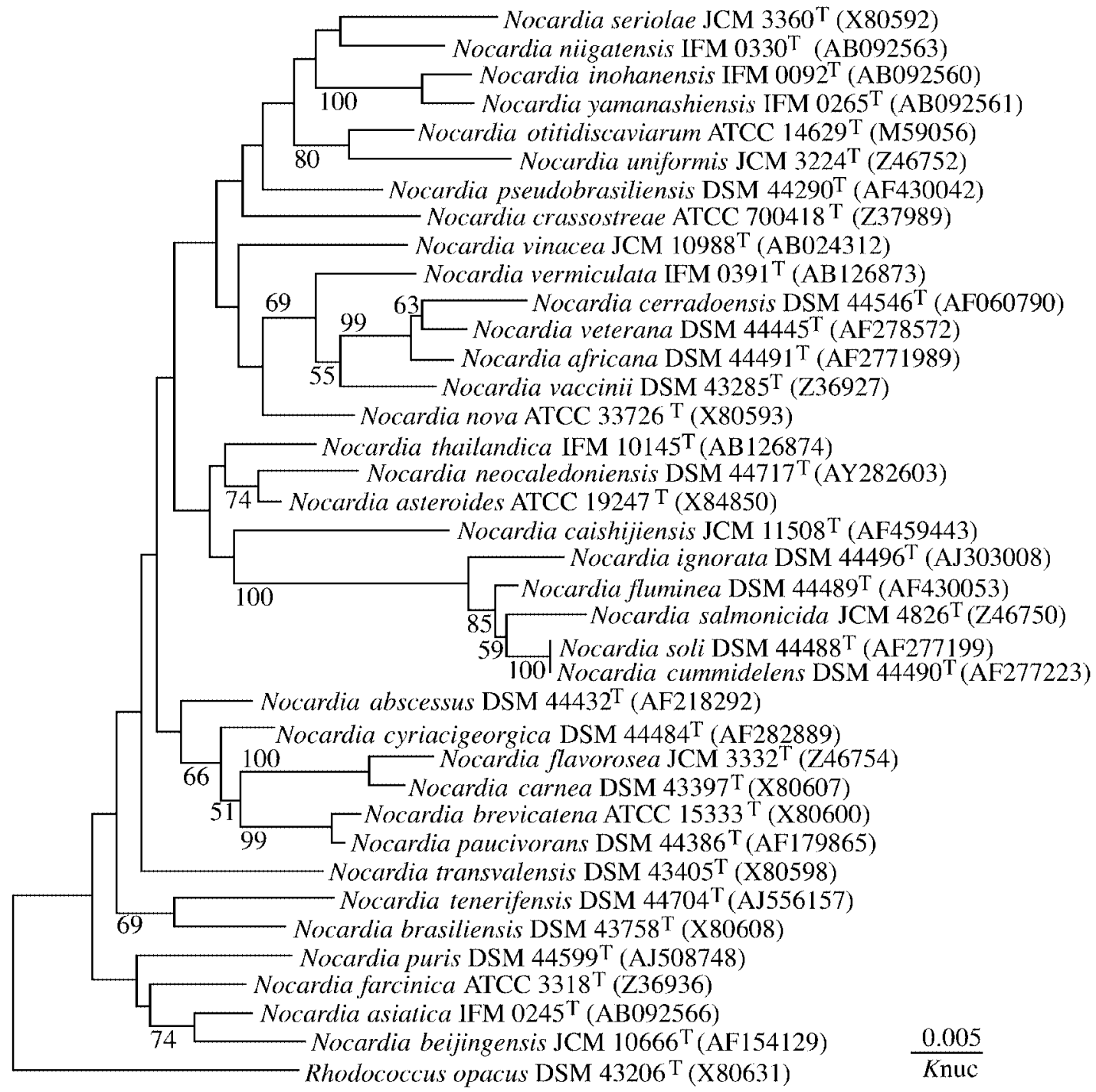

Fig. 1. Phylogenetic tree derived from $16 \mathrm{~S}$ rDNA sequences. The tree was created using the neighbor-joining method and KNUC values. The numbers on the tree indicate bootstrap values for the branch points. Only values above $50 \%$ significance are indicated. 


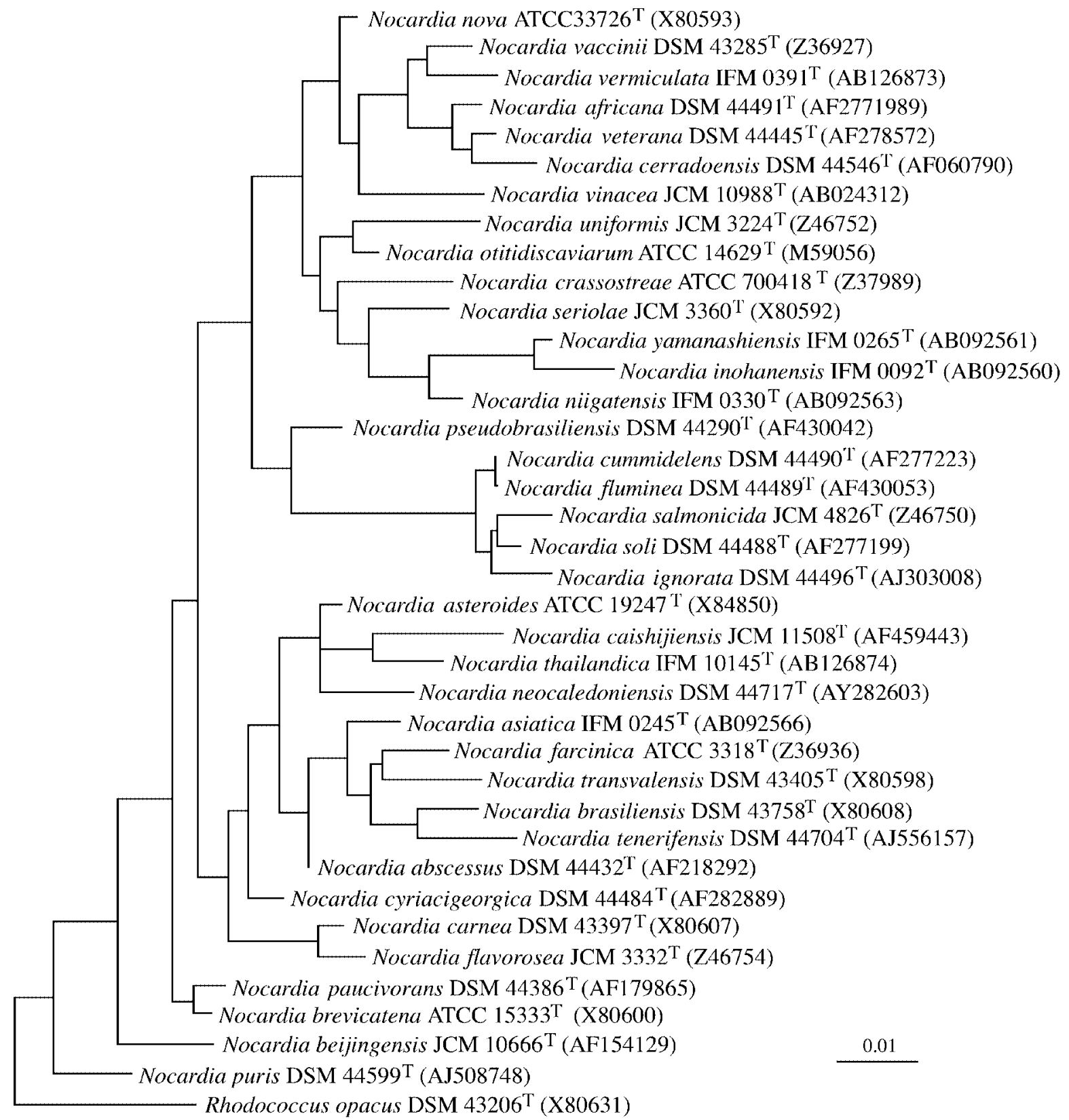

Fig. 2. Phylogenetic tree derived from 16S rDNA sequences. The tree was created using Maximum Likelihood analysis.

Table 3. Levels of DNA-DNA relatedness among IFM $0391^{\mathrm{T}}$ strain and related Nocardia species.

\begin{tabular}{|c|c|c|c|c|c|c|c|}
\hline & 1 & 2 & 3 & 4 & 5 & 6 & 7 \\
\hline 1. IFM $0391^{\mathrm{T}}$ & 100 & 8 & 9 & 10 & 6 & 7 & 2 \\
\hline 2. $N$. africana $\mathrm{IFM} 10147^{\mathrm{T}}$ & 10 & 100 & 11 & 3 & 10 & 3 & 3 \\
\hline 3. N. cerradoensis IFM $10366^{\mathrm{T}}$ & 9 & 12 & 100 & 11 & 43 & 38 & 13 \\
\hline 4. N. nova IFM $290^{\mathrm{T}}$ & 11 & 2 & 10 & 100 & 10 & 7 & 2 \\
\hline 5. N. vaccinii IFM $10284^{\mathrm{T}}$ & 10 & 10 & 41 & 13 & 100 & 46 & 13 \\
\hline 6. N. veterana IFM $10086^{\mathrm{T}}$ & 1 & 4 & 37 & 12 & 42 & 100 & 5 \\
\hline 7. N. vinacea IFM $10175^{\mathrm{T}}$ & 2 & 2 & 13 & 3 & 5 & 3 & 100 \\
\hline
\end{tabular}




\section{Description of Nocardia thailandica sp. nov.}

Nocardia thailandica (N.L. fem. adj. thailandica, referring to Thailand, where the type strain was isolated).

Colonies are grayish orange to tan. Cells show typical Nocardia micromorphology (branched vegetative mycelium that fragment into bacteroid, rod-shaped elements; $0.4-0.6$ by $0.8-1.6 \mu \mathrm{m})$. The aerial mycelium is visible and long in most media tested such as BHI agar plate. No soluble pigment is produced. Colonies are $0.2-1.2 \mathrm{~mm}$ in diameter after 7 days at $30^{\circ} \mathrm{C}$ on $\mathrm{MH} 11$ agar with $0.2 \%$ glucose. Glucose and mannose are utilized, but arabinose, erythritol, galactose, inositol, maltose, mannose, rhamnose, sorbitol, xylose, citrate and gluconate are not. Adenine, casein, hypoxanthine, tyrosine, xanthine, and elastine are not decomposed. Urea is not decomposed. Strain grows at $37^{\circ} \mathrm{C}$ but not at $45^{\circ} \mathrm{C}$. The $\mathrm{G}+\mathrm{C}$ content of the DNA is $72 \mathrm{~mol} \%$. The strain is a clinical isolate. The type strain of Nocardia thailandica is IFM $10145^{\mathrm{T}}\left(=\mathrm{NBRC} 100428^{\mathrm{T}}=\right.$ JCM $12356^{\mathrm{T}}=$ DSM $44808^{\mathrm{T}}$ ).

\section{REFERENCES}

1) McNeil, M. M. \& J. M. Brown: The medically important aerobic actinomycetes: epidemiology and microbiology. Clin. Microbiol. Rev. 7: 357-417, 1994

2) Gordon, R. E.; D. A. Barnett, J. E. Handerhan \& C. H. N. Pang: Nocardia coeliaca, Nocardia autotrophica, and the nocardin strain. Int. J. Syst. Bacteriol. 24: 54-63, 1974

3) Goodfellow, M.: Nocardia and related genera. In Topley and Wilson's Microbiology and Microbial Infections, 9th edn, vol. 2, (ed. A. Balows \& B. I. Duerden) pp. 463-489. Systematic Bacteriology, London, Arnold, 1997

4) Boiron, P.; F. Provost, G. Chevrier \& B. Dupont: Review of nocardial infections in France 1987 to 1990. Eur. J. Clin. Infect. Dis. 11: 709-714, 1992

5) McNeil, M. M.; M. J. Brown, P. R. Georghiou, A. M. Allworth \& Z. M. Blacklock: Infections due to Nocardia transvalensis: Clinical spectrum and antimicrobial therapy. Clin. Infect. Dis. 15: 453-463, 1992.

6) Beaman, B. L. \& L. Beaman: Nocardia species: host-parasite relationship. Clin. Microbiol. Rev. 7: 213-264, 1994

7) Poonwan, N.; M. Kusum, Y. Mikami, K. Yazawa, Y. Tanaka, T. Gonoi, S. Hasegawa \& K. Konyama: Pathogenic Nocardia isolated from clinical specimens including those of AIDS patients in Thailand. Eur. J. Epidemiol. 11: 507-512, 1995

8) Javaly, K.; H. W. Horowitz \& G. P. Wormser: Nocardiosis in patients with human immunodeficiency virus infection. Medicine (Baltimore) 71: 128-138, 1992

9) Schaal, K. P. \& H. Reuterberg: Numerical taxonomy of Nocardia asteroides. Zentbl. Bakteriol. Parasitol. Infekt. Hyg. I. Abt. Suppl. 6: 53-62, 1978

10) Orchard, V. A. \& M. Goodfellow: Numerical classification of some named strains of Nocardia asteroides and related isolates from soil. J. Gen. Microbiol. 118: 295-312, 1980

11) Gordon, R. E. D.; A. Barnett, J. E. Handerhan \& C. N. N.
Pang: Nocardia coeliaca, Nocardia autotrophica, and the nocardin strain. Int. J. Syst. Bacteriol. 24: 54-63, 1974

12) Mikami, Y. \& K. Yazawa: Susceptibility patterns of pathogenic Nocardia to some selected antimicrobial agents and their usefulness in the identification work in a clinical laboratory. Bull. JFCC. 5: 89-95, 1989

13) Staneck, J. L. \& G. D. Roberts: Simplified approach to identification of aerobic actinomycetes by thin-layer chromatography. Appl. Microbiol. 28: 226-231, 1974

14) Lechevalier, M. P. \& H. A. Lechevalier: The chemotaxonomy of actinomycetes. In Actinomycete taxonomy. (ed. A. Dietz \& D. W. Thayer), pp. 227-291. Society for Industrial Microbiology, Virginia, 1980

15) Miyadoh, M.: Identification procedure at the genus level. In Identification Manual of Actinomycetes (ed. S. Miyadoh, M. Hamada, K. Hotta, T. Kudo, A. Seino, K. Suzuki \& A. Yokota), pp. 9-19. Business Center for Academic Societies Japan, Tokyo, 2001

16) Minnikin, D. E.; I. G. Hutchinson, A. B. Caldicott \& M. Goodfellow: Thin-layer chromatography of methanolysates of mycolic acid-containing bacteria. J. Chromatography. 188: 221-233, 1980

17) Chun, J. \& M. Goodfellow: A phylogenetic analysis of genus Nocardia with $16 \mathrm{~S}$ rRNA gene sequences. Int. J. Syst. Bacteriol. 45: 240-245, 1995

18) Linos, A.; M.M. Berekaa, A. Steinbuchel, K.K. Kim, C. Sproer \& M. Kroppenstedt: Gordonia westfalica sp. nov., a novel rubber-degrading actinomycetes. Int. J. Syst. Evol. Microbiol. 50: 2031-2036, 2002

19) Sasser, M.: Identification of bacteria by gas chromatography of cellular fatty acids. USFCC Newsl. 20: 1-6, 1990

20) Kämpfer, P. \& R.M. Kroppenstedt: Numerical analysis of fatty acid patterns of coryneform bacteria and related taxa. Can. J. Microbiol. 42: 989-1005, 1996

21) Kageyama, A.; K. Yazawa, K. Nishimura \& Y. Mikami: Nocardia inohanensis sp. nov., Nocardia yamanashiensis sp. nov., and Nocardia niigatensis sp. nov. isolated from clinical specimens. Int. J. Syst. Evol. Microbiol. 53: 29-33, 2003

22) Kageyama, A.; N. Poonwan, K. Yazawa, Y. Mikami \& K. Nishimura: Nocardia asiatica sp. nov., isolated from patients with nocardiosis in Japan and clinical specimens in Thailand. Int. J. Syst. Evol. Microbiol. 54: 125-130, 2004

23) Kimura, M. \& T. Ohta: On the stochastic model for estimation of mutation distance between homologous proteins. J. Mol. Evol. 2: 87-90, 1972

24) Saitou, N., \& M. Nei: The neighbor-joining method: a new method for reconstructing phylogenetic trees. Mol. Biol. Evol. 4: 406-425, 1987

25) Thompson, J. D.; D. G. Higgins \& T. J. Gibson: CLUSTAL $\mathrm{W}$ : Improving the sensitivity of progressive multiple sequence alignment through sequence weighting, position specific gap penalties and weight matrix choice. Nucleic. Acids. Res. 22: 4673-4680, 1994

26) Felsenstein, J: Confidence limits on phylogenies: An approach using the bootstrap. Evolution. 39: 783-791, 1985.

27) Saito, H. \& K. Miura: Preparation of transforming deoxyribonucleic acid by phenol treatment. Biochem. Biophys. Acta. 72: 619-629, 1983

28) Tamaoka, J. \& K. Komagata: Determination of DNA base composition by reversed-phase high-performance liquid chromatography. FEMS. Microbiol. Lett. 25: 125-128, 1984

29) Ezaki, T.; Y. Hashimoto \& E. Yabuuchi: Fluorometric deoxyribonucleic acid-deoxyribonucleic acid hybridization 
in microdilution wells as an alternative to membrane filter hybridization in which radioisotopes are used to determine genetic relatedness among bacterial strains. Int. J. Syst. Bacteriol. 39: 224-229, 1989

30) Goodfellow, M.: Nocardia and related genera. In Topley and Wilson's Microbiology and Microbial Infections, 9 th edn, vol. 2, Systematic Bacteriology, (ed. A. Balows \& B. I. Duerden) pp. 463-489, London, Arnold, 1998

31) Goodfellow, M.; K. Isik \& E. Yates: Actinomycete systematics: an unfinished synthesis. Nova. Acta. Leopold. 80(312): 47-82, 1999

32) Stackebrandt, E.; F. A. Rainey \& N. L. Ward-Rainey: Proposal for a new hierarchic classification system, Actinobacteria class nov, Int. J. Syst. Bacteriol. 47: 479-491, 1997

33) Albuquerque, B.; E. V. S. Manfio, G. P. Maitan, V. R. Bataus, L. A. M. Kim, S. B. Maldonado, L. A. \& M. Goodfellow: Nocardia cerradoensis sp. nov., a novel isolate from Cerrado soil in Brazil. Int. J. Syst. Evol. Microbiol. 53: 29-33, 2003

34) Gurtler, V.; R. Smith, B. C. Mayall, G. Pötter-Reinemann, E. Stackebrandt \& R. M. Kroppenstedt: Nocardia veterana sp. nov., isolated from human bronchial lavage. Int. J. Syst. Evol. Microbiol. 51: 933-936, 2001

35) Hamid, M. E.; L. Maldonado, G. S. Sharaf Eldin, M. F. Mohamed, N. S. Saeed \& M. Golloe: Nocardia africana sp. nov., a new pathogen isolated from patients with pulmonary infections. J. Clin. Microbiol. 39: 625-630, 2001

36) Kämper, P.; S. Buczolits, U. Jäckel, I. Grün-Wollny \& H.J. Busse: Nocardia tenerifensis sp. nov. Int. J. Syst. Evol. Microbiol. 54: 381-383, 2004
37) Kinoshita, N.; Y. Homma, M. Igarashi, S. Ikeno, M. Hori \& M. Hamada: Nocardia vinacea sp. nov. Actinomycetol. $15,1-5,2001$

38) Maldonado, L.; J. V. Hookey, A. C. Ward \& M. Goodfellow: The Nocardia salmonicida clade, including descriptions of Nocardia cummidelens sp. nov., Nocardia fluminea sp. nov. and Nocardia soli sp. nov. Antonie. Leeuwenhoek. 78: 367-377, 2000

39) Saintpierre-Bonaccio, D; A.M. Maldonado, H. Amir, R. Pineau \& M. Goodfellow: Nocardia neocaledoniensis sp. nov., a novel actinomycete isolated from a New-Caledonian brown hypermagnesian ultramafic soil. Int. J. Syst. Evol. Microbiol. 54: 599-603, 2004

40) Wang, L.; Y. Zhang, Z. Lu, Y. Shi, Z. Liu, L. Maldonado \& M. Goodfellow: Nocardia beijingensis sp. nov., a novel isolate from soil. Int. J. Syst. Evol. Microbiol. 51: 1783-1788, 2001

41) Yassin, A. F.; F. A. Rainey, U. Mendrock, H. Brzezinka \& K. P. Schaal: Nocardia abscessus sp. nov. Int. J. Syst. Evol. Microbiol. 50: 1487-1493, 2000

42) Yassin, A. F.; F. A. Rainey \& U. Steiner: Nocardia cyriacigeorgici sp. nov. Int. J. Syst. Evol. Microbiol. 51: 1419-1423, 2001

43) Yassin, A. F.; F. A. Rainey \& U. Steiner: Nocardia ignorata sp. nov. Int. J. Syst. Evol. Microbiol. 51: 2127-2131, 2001.

44) Yassin, A. F.; B. Straubler, P. Schumann \& K. P. Schaal: Nocardia puris sp. nov. Int. J. Syst. Evol. Microbiol. 53: 1595-1599, 2003

45) Zhang, J.; L. Zhiheng \& M. Goodfellow: Nocardia caishijiensis sp. nov., a novel soil actinomycete. Int. J. Syst. Evol. Microbiol. 53: 999-1004, 2003 